\title{
Reduced fat and sugar vanilla ice creams: Sensory profiling and external preference mapping
}

\author{
R. S. Cadena, ${ }^{1}$ A. G. Cruz, J. A. F. Faria, and H. M. A. Bolini \\ Universidade Estadual de Campinas (UNICAMP), Faculdade de Engenharia de Alimentos (FEA), CEP 13083-862, Campinas, São Paulo, Brazil
}

\begin{abstract}
The aims of this study were (1) to map sensory attributes of vanilla ice cream with reduced fat and sugar, and (2) to determine drivers of liking by applying external preference mapping and reveal the relationship between descriptive attributes and hedonic judgments using the partial least squares method. Descriptive sensory profiles $(\mathrm{n}=11)$ and consumer test $(\mathrm{n}=117)$ of 6 samples of vanilla ice cream (3 traditional and 3 with reduced fat and sugar) were determined. The attributes brightness and sweet aftertaste for sample and creaminess (appearance and texture) and sweet aroma contributed positively to the acceptance of ice cream samples. The attributes aeration, powdered milk aroma and flavor, and white chocolate aroma and flavor contributed positively to the acceptance of the ice creams. The attributes hydrogenated fat aroma and flavor were responsible for the lower acceptance of samples. The reduction in fat and sugar did not necessarily cause a decrease in acceptance. The most important factors were selection of the appropriate sweetener system and the use of good quality raw material.
\end{abstract}

Key words: sensory profiling, ice cream, partial least squares, sweetener

\section{INTRODUCTION}

The combination of lifestyle-related diseases such as diabetes mellitus, hypertension, hyperlipidemia, and atherosclerosis is called metabolic syndrome (Higurashi et al., 2007). The prevalence of metabolic syndrome is increasing in tandem with rising levels of obesity and sedentary lifestyles (Weiss et al., 2004). Obesity affects more than $50 \%$ of adults and around one-third of children in different countries (Saris, 2003). The etiology of obesity is complex but essentially involves an excess of energy intake over energy expenditure (Ruxton et al., 2010).

Received March 11, 2012.

Accepted May 4, 2012.

${ }^{1}$ Corresponding author: racadena@fea.unicamp.br
In principle, sugar and fat can increase the risk of obesity by increasing the energy density of the diet or by making energy-dense foods more palatable (Ruxton et al., 2010). In many studies, the overconsumption of high-fat foods has been linked to the increasing incidence of obesity (Astrup et al., 1997; Schrauwen and Westerterp, 2000; Kuo et al., 2008; La Serre et al., 2010). However, the increase in sugar intake is more associated with other diseases and cancer, than with obesity (Ruxton et al., 2010).

It has become clear that adjustments in dietary habits are very important to combating the metabolic syndrome, and the growing interest in healthy eating has given rise to new foods and products on the market (Bayarri et al., 2011). Nonetheless, modifications in the composition of these products and the amounts of fat and sugar result in variations in the flavor and texture, which are key factors for the success of a product on the market (Hatchwell, 1994; Guinard et al., 1996; Caillet et al., 2003; Ozdemir et al., 2008).

High-intensity sweeteners and fat replacers are successful if they match perfectly the quality of sucrose and milk fat (Portmann and Kilcast, 1996). However, the replacement of sucrose by alternative sweeteners can result in changes in the perception of sweet and bitter taste (Bolini et al., 1999). Additionally, the substitution of fat decreases the sensation of creaminess (Karaca et al., 2009). The commercial success of a food on the consumer market necessarily implies that it has sensory characteristics well accepted by the consumer market, safety characteristics for consumption, and nutritional qualities (Cruz et al., 2010).

Ice cream is a highly complex food matrix and can be considered as an aerated suspension of fat and water in a concentrated sugar solution that includes stabilizers, casein micelles, and proteins (Frøst et al., 2005; Erkaya et al., 2012). In addition to being one of the most consumed dairy products in the world (Sun-Waterhouse et al., 2011), ice cream is the most popular semi-solid dairy dessert, with the additional advantage of being an appropriate matrix for supplementation with probiotic bacteria and prebiotic ingredients (Cruz et al., 2009; Soukoulis et al., 2009; Di Criscio et al., 2010; Isik et al., 2011; Ferraz et al., 2012). However, little information 
exists about the influence of high-intensity sweeteners and fat replacers on the perception of sensory attributes by trained assessors and consumers. The aims of this study were (1) to map sensory attributes of commercial vanilla ice cream with reduced fat and sugar, and (2) to determine drivers of liking, applying external preference mapping, and reveal the relationship between descriptive attributes and hedonic judgments using partial least squares (PLS) regression analysis.

\section{MATERIALS AND METHODS}

\section{Ice Cream Samples}

Three brands of commercial Brazilian vanilla ice cream were used in this study (Table 1). The 3 brands had different positions on the consumer market. The first brand was the leader on the Brazilian market (Trad-1; Light-1), the second brand was recognized as being of high quality (Trad-2; Light-2), and the third was a new brand on the market (Trad-3; Light-3). According to the Brazilian legislation, to be considered "light," food needs to present a minimum reduction of $25 \%$ of the total energy or total sugars or total lipids (Brasil, 1998).

The samples were purchased at a supermarket and stored in a horizontal freezer at $-18^{\circ} \mathrm{C} \pm 2^{\circ} \mathrm{C}$, similar to conditions reported in previous studies (Thompson et al., 2009). These brands, and the vanilla flavor, were chosen because they were the only ones offering both traditional and reduced sugar and fat versions. In addition, vanilla is one of the most popular ice cream flavors in Brazil and other countries, including the United States, Canada, Germany, France, Italy, United Kingdom, and Japan (Euromonitor International, 2002).

\section{Sensory Profiling}

The sensory profiling was established using quantitative descriptive analysis (QDA; Stone and Sidel, 2004), a popular sensory descriptive method used in several studies covering dairy foods (Allgeyer et al., 2010; Ritvanen et al., 2010; Wadhwani and McMahon, 2012). Eleven assessors (4 men and 7 women) participated in this study, all recruited at the University of Campinas (São Paulo, Brazil) and preselected based on interest, availability, nonsmoker status, and lack of food allergies. Their mean age was 25 yr. Kelly's repertory grid method (Moskowitz, 1983) was used to determine the attributes of ice cream samples, and 22 descriptor terms were developed. Table 2 shows the sensory attributes used in the sensory evaluation as well as their definitions and the standards used for assessor training. Eight 2-h training sessions were conducted to form the same sensory memory in the assessors by use of anchors (minimum and maximum) for the intensity scale of each descriptor term.

The analysis was carried out over a 4-d period and each sample was evaluated in $15 \mathrm{~min}$ in one session per replication. Each sample was evaluated 4 times. Using a balanced complete block design (MacFie et al., 1989), all samples were offered in plastic cups, coded with 3-digit numbers, with a transparent plastic spoon. Fifty-gram samples of vanilla ice cream at a temperature of $-10^{\circ} \mathrm{C} \pm 2^{\circ} \mathrm{C}$ were offered, as in a previous study (Guinard et al., 1997). The assessors were instructed to rinse their mouths with distilled water between samples to avoid the "cold" carry-over effect (Guinard et al. 1997). A 9-cm linear scale (not structured) was used for each descriptor term, anchored at the ends by "none" or "low" on the left and "strong" on the right (Stone and Sidel, 2004; Meilgaard et al., 2007).

\section{Consumer Test}

One hundred seventeen consumers were recruited to participate in the ice cream acceptance test at the University of Campinas. The selection criterion was that subjects had to consume ice cream at least once a week and be adults over 18 yr of age (Dooley et al., 2010).

The consumers received the samples in a monadic presentation. Twenty grams of vanilla ice cream at

Table 1. Nutritional composition (\%; g/100 g of ice cream, according to label) and sweetener system of commercial ice cream

\begin{tabular}{lcccrl}
\hline Brand & Sample $^{1}$ & Carbohydrate & Protein & Lipid & Sweetener system \\
\hline \multirow{2}{*}{2} & Trad-1 & 25.0 & 2.8 & 7.5 & Sucrose \\
& Light-1 & 6.7 & 4.3 & 3.3 & Sorbitol, aspartame, sodium cyclamate \\
& Trad-2 & 21.7 & 3.3 & 14.1 & Sucrose \\
& Light-2 & 18.3 & 4.8 & 3.3 & Sorbitol, sucralose \\
& Trad-3 & 18.3 & 1.7 & 7.5 & Sucrose \\
& Light-3 & 12.5 & 4.4 & 4.7 & Sorbitol, lactitol, aspartame \\
\hline
\end{tabular}

${ }^{1}$ Trad $=$ traditional ice cream; Light $=$ vanilla ice cream with reduced fat and sugar, where 1,2 , and 3 represent the Brazilian brand leader, a high-quality brand, and a brand new to the market, respectively. 
Table 2. Descriptors used for the sensory profiling of vanilla ice creams

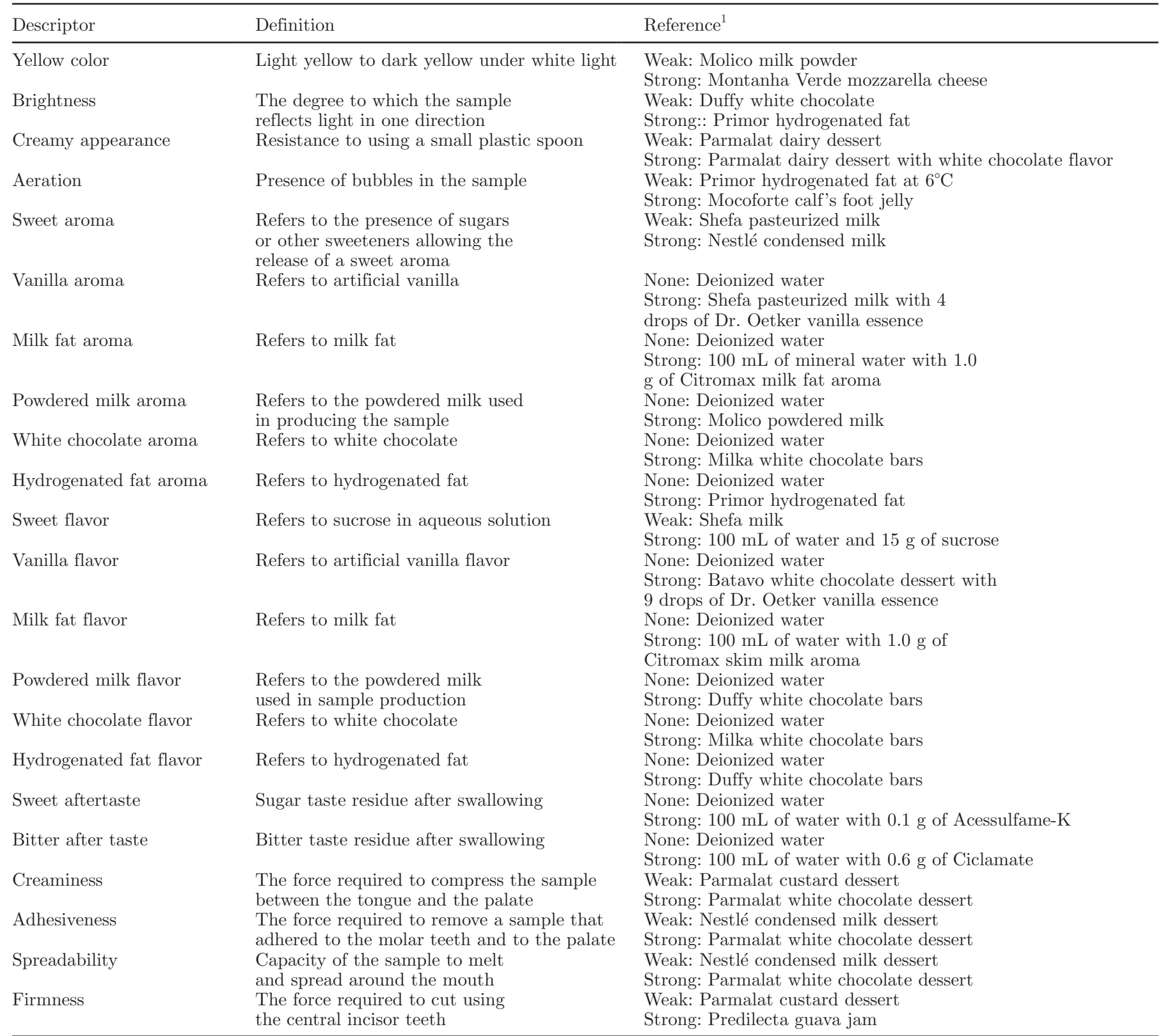

${ }^{1}$ Molico (Nestlé, São Paulo, Brazil); Montanha Verde (Sadia, São Paulo, Brazil); Duffy (Pirajá, Bahia, Brazil); Primor (Bunge, São Paulo, Brazil); Parmalat (Parmalat, São Paulo, Brazil); Shefa (Ribeirão Preto, São Paulo, Brazil); Nestlé (São Paulo, Brazil); Dr. Oetker (São Paulo, São Paulo, Brazil); Batavo (Batavo, São Paulo, Brazil); Predilecta (Predilecta, São Paulo, Brazil); Citromax (Citromax, São Paulo, Brazil); Milka (Lacta, São Paulo, Brazil); Sucrose (União, Rio de Janeiro, Brazil); Ciclamate (Gold Nutrition, São Paulo, Brazil); and Acessulfame K (Master Sense, São Paulo, Brazil).

a temperature of $-10^{\circ} \mathrm{C} \pm 2^{\circ} \mathrm{C}$ was offered in plastic cups, coded with 3-digit numbers, together with a transparent plastic spoon (Guinard et al., 1997). Acceptance was determined in relation to overall liking using a 9-cm linear scale (not structured), with anchors of "dislike extremely" on the left and "like extremely" on the right. All samples were presented in a balanced order using a balanced complete block design (MacFie et al., 1989). The subjects were instructed to rinse their mouths with distilled water between samples to avoid the "cold" carry-over effect (Guinard et al., 1997). To prevent bias, no information about the samples was given to the consumers (Thompson et al., 2009). 


\section{Statistical Analysis}

Analysis of variance was carried out for each attribute to monitor panel performance (ability to discriminate, reproducibility, and consistency among assessors). Ten panelists out of 11 were chosen to participate according to their discriminating capability $(P<0.30)$ and repeatability $(P>0.05)$, and an individual consensus was also considered (Damásio and Costell, 1991) in addition to the sensory descriptive data and consumer test data. Tukey's honestly significant difference multiple comparison tests were applied to compare the attribute level differences among samples, considering a $5 \%$ significance level $(P<0.05)$. Results of the tests were analyzed using SAS software (2008; SAS Institute Inc., Cary, NC).

Correlation between the QDA and consumer test data was determined by PLS regression analysis (Tenenhaus et al., 2005) using the software XLStat 2007 (Addinsoft, Paris, France). The overall impression was the dependent variable (Y-matrix), and the QDA attributes were the independent variables (X-matrix; Braghieri et al., 2009). Some recent studies have used PLS to report hedonic judgments and product characteristics (Pereira et al., 2005; Frandsen et al., 2007; Braghieri et al., 2009; Cruz et al., 2011; Bayarri et al., 2012) and to determine relevant sensory characteristics of milk commercial products (Ochi et al., 2010).

External preference mapping (PREFMAP; Kaaki et al., 2012) was conducted by first using principal components analysis (PCA) on the descriptive sensory analysis data and then relating each of the consumers to this PCA space by regression analysis. Consumers are usually represented as points or arrows on the sample map as in the internal analysis (Helgesen et al., 1997). The vector model, which implies a direct relationship between one or more characteristics that are increasing or decreasing across the stimulus space, was used. Thus, the more a characteristic was present, the more it was liked; alternatively, if it was a negative characteristic, the less the characteristic was present the less it was liked (Hough and Sanchez, 1998). The PREFMAP was carried out using XLStat 2007.

\section{RESULTS AND DISCUSSION}

\section{Sensory Profiling}

The results of the sensory profile of vanilla ice cream samples are reported in Table 3 . In appearance, sample Light-2 differed significantly from the others $(P<0.05)$ in yellow color and brightness, with more intense values for these attributes, whereas the traditional ice cream samples (Trad-1, Trad-2, Trad-3) had a creamier appearance and aeration (air holes). These 2 attributes can be directly affected by the fat content (Soukoulis et al., 2010b) and by fat replacers (bulking agents, concentrated milk components, and others) used (Roland et al., 1999). Light ice cream samples have a lower fat content, and the fat replacers used in the manufacture of this ice cream are not as efficient as fat in retaining air and forming air cells (Marshall and Arbuckle, 1996; Sofjan and Hartel, 2004). Sample Light-2 had values for creamy appearance and aeration closest to those of the traditional samples.

Concerning the attributes of aroma, both samples of brand 2 showed more intensity $(P<0.05)$ for powdered milk and white chocolate aromas. Moreover, along with sample Trad-1, both samples of brand 2 had a sweeter aroma. Both samples of brand 3, which is new on the market, showed greater intensity $(P<0.05)$ of hydrogenated fat aroma.

In relation to flavor, both samples of brand 2 showed more intensity $(P<0.05)$ of powdered milk and white chocolate flavors, and ice creams of brand 3 had greater intensity of hydrogenated fat flavor. Two samples with a lower fat content (Light-1 and Light-2) showed less intensity of the attributes directly related to fat (milk and hydrogenated fat). Hyvönen et al. (2003) found similar results for a decreased fat content in strawberryflavored ice cream samples.

Both Trad and Light samples of brands 1 and 3 showed a significant difference $(P<0.05)$ in relation to sweetness. The traditional samples of these brands were sweeter and the difference in sweetness was probably not due to replacement of the milk fat by fat replacers, but rather to the nonequivalent use of sweetener in the light counterparts (Ohmes et al., 1998).

Li et al. (1997), Chung et al. (2004), and Thompson et al. (2009) determined that a higher fat level in ice creams enhances the overall perception of vanilla intensity, which explains the lesser intensity of vanilla flavor in samples Light-1 and Light-2, which had a lower fat content.

Samples Light-1 and Light-3 differed from the others $(P<0.05)$ for bitter aftertaste, showing higher means, probably due to the use of aspartame and sodium cyclamate as the sweetener system (Calviño et al., 2000; King et al., 2000; Cardoso and Bolini, 2008). Sample Light-2, which had sucralose as the sweetener system, showed greater intensity $(P<0.05)$ for sweet aftertaste than the other samples, in agreement with previous studies using ice creams sweetened with sucralose (Hanger et al., 1996; Melo et al., 2009).

Finally, for texture, sample Trad-2 was rated as having more creaminess $(P<0.05)$, probably because 
Table 3. Sensory profile attribute means and overall liking for each sample

\begin{tabular}{|c|c|c|c|c|c|c|}
\hline \multirow[b]{2}{*}{ Attribute } & \multicolumn{6}{|c|}{ Sample $^{1}$} \\
\hline & Trad-1 & Light-1 & Trad-2 & Light-2 & Trad-3 & Light-3 \\
\hline \multicolumn{7}{|l|}{ Appearance } \\
\hline Yellow color & $5.30^{\mathrm{b}}$ & $5.30^{\mathrm{b}}$ & $1.44^{\mathrm{d}}$ & $7.69^{\mathrm{a}}$ & $4.01^{\mathrm{c}}$ & $1.32^{\mathrm{d}}$ \\
\hline Brightness & $3.66^{\mathrm{c}}$ & $2.85^{\mathrm{d}}$ & $4.51^{\mathrm{b}}$ & $5.27^{\mathrm{a}}$ & $4.19^{\mathrm{bc}}$ & $1.97^{\mathrm{e}}$ \\
\hline Creamy appearance & $5.10^{\mathrm{a}}$ & $3.40^{\mathrm{c}}$ & $5.16^{\mathrm{a}}$ & $4.21^{\mathrm{b}}$ & $5.01^{\mathrm{a}}$ & $2.23^{\mathrm{d}}$ \\
\hline Aeration & $5.35^{\mathrm{a}}$ & $3.51^{\mathrm{c}}$ & $5.37^{\mathrm{a}}$ & $4.87^{\mathrm{b}}$ & $5.76^{\mathrm{a}}$ & $2.40^{\mathrm{d}}$ \\
\hline \multicolumn{7}{|l|}{ Aroma } \\
\hline Sweet & $5.26^{\mathrm{a}}$ & $3.90^{\mathrm{b}}$ & $5.27^{\mathrm{a}}$ & $4.97^{\mathrm{a}}$ & $3.95^{\mathrm{b}}$ & $4.23^{\mathrm{b}}$ \\
\hline Vanilla & $3.92^{\mathrm{a}}$ & $2.19^{\mathrm{c}}$ & $3.12^{\mathrm{b}}$ & $2.47^{\mathrm{c}}$ & $2.55^{\mathrm{bc}}$ & $2.52^{\mathrm{c}}$ \\
\hline Milkfat & $2.34^{\mathrm{bc}}$ & $1.78^{\mathrm{c}}$ & $3.41^{\mathrm{a}}$ & $2.26^{\mathrm{bc}}$ & $2.17^{\mathrm{bc}}$ & $2.45^{\mathrm{b}}$ \\
\hline Powdered milk & $1.47^{\mathrm{b}}$ & $1.13^{\mathrm{c}}$ & $2.62^{\mathrm{a}}$ & $2.16^{\mathrm{a}}$ & $1.19^{\mathrm{bc}}$ & $0.72^{\mathrm{c}}$ \\
\hline White chocolate & $2.00^{\mathrm{c}}$ & $1.21^{\mathrm{d}}$ & $4.49^{\mathrm{a}}$ & $3.69^{\mathrm{b}}$ & $0.91^{\mathrm{d}}$ & $0.74^{\mathrm{d}}$ \\
\hline Hydrogenated fat & $0.64^{\mathrm{d}}$ & $1.10^{\mathrm{c}}$ & $0.32^{\mathrm{d}}$ & $0.49^{\mathrm{d}}$ & $2.02^{\mathrm{b}}$ & $4.19^{\mathrm{a}}$ \\
\hline \multicolumn{7}{|l|}{ Flavor } \\
\hline Sweet & $6.36^{\mathrm{b}}$ & $4.64^{\mathrm{cd}}$ & $7.43^{\mathrm{a}}$ & $7.47^{\mathrm{a}}$ & $5.06^{\mathrm{c}}$ & $4.28^{\mathrm{d}}$ \\
\hline Vanilla & $3.55^{\mathrm{ab}}$ & $2.69^{\mathrm{cd}}$ & $3.33^{\mathrm{b}}$ & $2.50^{\mathrm{d}}$ & $3.13^{\mathrm{c}}$ & $4.15^{\mathrm{a}}$ \\
\hline Milkfat & $3.78^{\mathrm{a}}$ & $2.61^{\mathrm{b}}$ & $2.86^{\mathrm{b}}$ & $2.73^{\mathrm{b}}$ & $1.95^{\mathrm{c}}$ & $2.58^{\mathrm{b}}$ \\
\hline Powdered milk & $1.87^{\mathrm{b}}$ & $1.30^{\mathrm{c}}$ & $3.48^{\mathrm{a}}$ & $3.01^{\mathrm{a}}$ & $1.02^{\mathrm{c}}$ & $0.82^{\mathrm{c}}$ \\
\hline White chocolate & $0.90^{\mathrm{c}}$ & $2.90^{\mathrm{b}}$ & $0.70^{\mathrm{c}}$ & $0.97^{\mathrm{c}}$ & $3.37^{\mathrm{b}}$ & $5.36^{\mathrm{a}}$ \\
\hline Hydrogenated fat & $2.81^{\mathrm{b}}$ & $0.95^{\mathrm{c}}$ & $5.27^{\mathrm{a}}$ & $4.66^{\mathrm{a}}$ & $1.03^{\mathrm{c}}$ & $0.42^{\mathrm{c}}$ \\
\hline Sweet aftertaste & $2.32^{\mathrm{c}}$ & $2.28^{\mathrm{c}}$ & $3.06^{\mathrm{b}}$ & $4.43^{\mathrm{a}}$ & $1.78^{\mathrm{c}}$ & $2.16^{\mathrm{c}}$ \\
\hline Bitter aftertaste & $0.35^{\mathrm{d}}$ & $3.10^{\mathrm{a}}$ & $0.45^{\mathrm{d}}$ & $1.68^{\mathrm{c}}$ & $0.63^{\mathrm{d}}$ & $2.37^{\mathrm{b}}$ \\
\hline \multicolumn{7}{|l|}{ Texture } \\
\hline Creaminess & $5.22^{\mathrm{b}}$ & $3.10^{\mathrm{d}}$ & $6.27^{\mathrm{a}}$ & $4.26^{\mathrm{c}}$ & $4.79^{\mathrm{bc}}$ & $2.78^{\mathrm{d}}$ \\
\hline Adhesiveness & $4.98^{\mathrm{ab}}$ & $3.76^{\mathrm{c}}$ & $5.59^{\mathrm{a}}$ & $4.57^{\mathrm{b}}$ & $3.72^{\mathrm{c}}$ & $2.77^{\mathrm{d}}$ \\
\hline Spreadability & $3.73^{\mathrm{c}}$ & $3.68^{\mathrm{c}}$ & $4.12^{\mathrm{bc}}$ & $4.64^{\mathrm{ab}}$ & $4.65^{\mathrm{ab}}$ & $5.21^{\mathrm{a}}$ \\
\hline Firmness & $3.42^{\mathrm{c}}$ & $4.60^{\mathrm{b}}$ & $3.25^{\mathrm{c}}$ & $4.98^{\mathrm{b}}$ & $3.52^{\mathrm{c}}$ & $6.65^{\mathrm{a}}$ \\
\hline \multicolumn{7}{|l|}{ Acceptance test } \\
\hline Overall liking & $6.03^{\mathrm{ab}}$ & $5.22^{\mathrm{d}}$ & $6.00^{\mathrm{ab}}$ & $6.38^{\mathrm{a}}$ & $5.55^{\mathrm{cd}}$ & $5.35^{\mathrm{cd}}$ \\
\hline
\end{tabular}

${ }^{\mathrm{a} e}$ Means with the same letters in a row indicate that samples do not differ at a significance level of $5 \%$ by Tukey's test.

${ }^{1}$ Trad $=$ traditional ice cream; Light $=$ vanilla ice cream with reduced fat and sugar, where 1,2 , and 3 represent the Brazilian brand leader, a high-quality brand, and a brand new to the market, respectively.

of its high lipid content (Stampanoni-Koeferli et al., 1996; Guinard et al., 1997). In general, the traditional samples showed more creaminess, which demonstrates the difficulty of finding an acceptable formulation with respect to the ingredients used by the dairy processors. Similar results were obtained for full-fat and low-fat ice creams stored at storage temperatures from $-45^{\circ} \mathrm{C}$ from $-23^{\circ} \mathrm{C}$ (Buyck et al., 2011), where there was no effect of storage temperature on the acceptance of the samples.

The samples with fat and sugar replacers were shown to be firmer $(P<0.05)$ than the traditional ice cream samples. Roland et al. (1999) found the same results; that is, the removal or replacement of fat hardened the ice cream samples. Tharp et al. (1998) found that the firmness of ice cream increased as the level of PS80 (an oil-in-water emulsifier) or level of destabilized fat increased. BahramParvar et al. (2010) noted that stabilizers bind water, increasing the viscosity and enhancing the firmness of ice creams. Nevertheless, numerous factors (e.g., ice crystal content, ice crystal size, extent of fat destabilization, overrun, and the rheological properties of the mix) influence the firmness of ice cream (Muse and Hartel, 2004).

\section{Relationship of Descriptive Attributes and Acceptance Test}

Samples Trad-1, Trad-2, and Light-2 were the most accepted vanilla ice creams, with mean overall acceptance values ranging from 6.0 to 6.38 , whereas Light-1, Trad-3, and Light-3 were the least accepted samples, with mean values ranging from 5.22 to 5.55 .

The relationship found using PLS (Figure 1) explains the positive and negative attributes that were important to the consumer. The columns of attributes on the positive part of the y-axis (columns in black) are of positive importance in the characterization of the ice cream, whereas the columns on the negative part of the y-axis (columns in gray) represent attributes whose presence is negative with respect to acceptance of ice cream (Tenenhaus et al., 2005). When the standard deviation for an attribute does not cross the x-axis, it can be considered a major positive or negative at- 


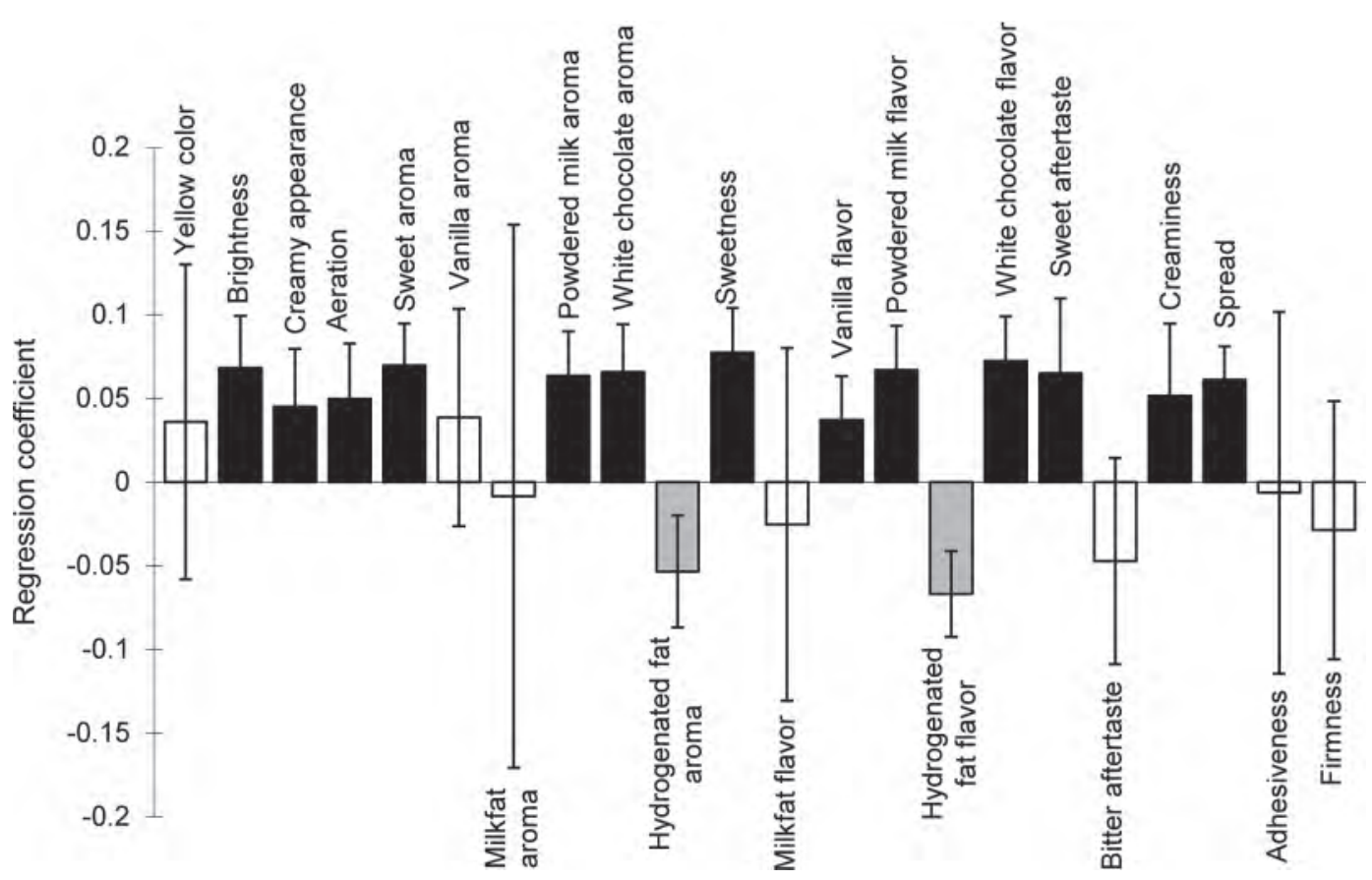

Figure 1. Partial least squares regression coefficients (black = descriptor terms that contribute positively to consumer acceptance; gray $=$ descriptor terms that contribute negatively to consumer acceptance; white $=$ descriptor terms without significant contribution to consumer acceptance).

tribute in the characterization of the ice cream at a $95 \%$ confidence level. The extent of the columns represents the importance of each attribute to the consumer, whether positive or negative. The attribute with the highest column, in either direction, is considered the most important attribute for a sample to have or not have (Tenenhaus et al., 2005).

The attributes of appearance (brightness, creamy appearance, and aeration) and aroma and flavor (sweetness, powdered milk, and white chocolate) contributed positively to the acceptance of the ice cream more than vanilla flavor, sweet aftertaste, and the attributes of texture (creaminess and spreadability). According to Soukoulis et al. (2010a), creaminess, mouth-coating, tongue, lubrication, friction, coarseness, and thickness are sensory attributes of paramount importance to the perception of quality of semi-solid dairy desserts. Only the aroma and hydrogenated fat flavor contributed to the rejection of the ice cream samples at a $95 \%$ confidence level.

\section{External Preference Mapping}

According to Guinard et al. (2001), the challenge of external preference mapping is the interpretation of the results, because preferences are expressed as a function of 2 or more principal components, not simple analytical variables. However, with this technique, it is possible to regress the hedonic ratings of each consumer onto a set of descriptive attributes.

The results of the external preference mapping are shown in Figure 2. For the PREFMAP analysis, 85\% of the sensory information explained $33 \%$ of the preference data (Lawlor and Delahunty, 2000). The data were found to explain 2 main components. The first, the horizontal component, was responsible for separating the attributes into 2 groups. The group of attributes responsible for good quality, such as creaminess (appearance and texture) and white chocolate flavor and aroma, is on the left and group of attributes with some off-flavors, such as bitter aftertaste and hydrogenated fat aroma and flavor, is on the right. The second component (vertical) was responsible for characterizing the samples with the attributes yellow color and bitter aftertaste and for grouping the consumers with their preferred samples, Light-1 and Light-2.

By examining the position of the consumers, it is possible to determine the least and most accepted samples (Guinard et al., 2001). The samples most accepted (Trad-1, Trad-2, and Light-2) were allocated to quadrants I $(\mathrm{X}-, \mathrm{Y}+)$ and III $(\mathrm{X}-, \mathrm{Y}-)$; consequently, these spaces had a higher density of consumers. Sample Light-2 was characterized by its yellow color and sweet aftertaste, whereas samples Trad-1 and Trad-2 were characterized by their milkfat aroma and flavor, sweet aroma, vanilla aroma, and creaminess (appearance and 


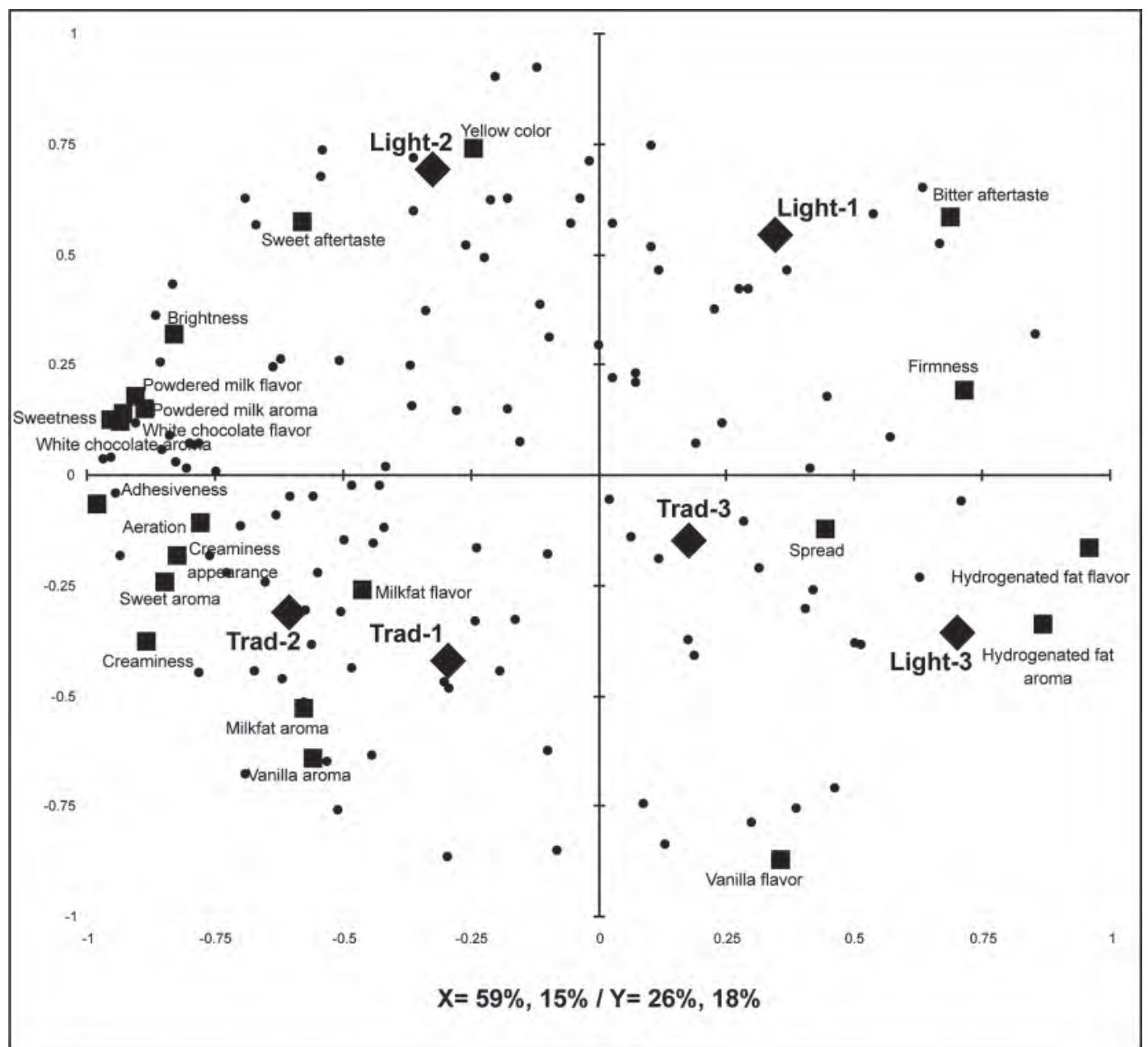

Figure 2. External preference map (X and Y are horizontal and vertical axes, respectively) obtained by partial least squares regression of descriptive data and respondents' overall liking scores for the sensory attributes of ice cream samples (diamond $=$ samples; square $=$ attributes of quantitative descriptive analysis; circle $=$ consumers $)$. Trad $=$ traditional ice cream; Light $=$ vanilla ice cream with reduced fat and sugar; and 1,2, and 3 represent the Brazilian brand leader, a high-quality brand, and a brand new to the market, respectively.

texture). The least accepted samples (Light-1, Trad-3, and Light-3) were allocated to quadrants I $(\mathrm{X}+, \mathrm{Y}+)$ and IV $(\mathrm{X}+, \mathrm{Y}-)$. Sample Light-1 was characterized by bitter aftertaste and firmness, and samples Trad-3 and Light-3 were characterized by hydrogenated aroma and flavor and spreadability.

\section{CONCLUSIONS}

The trained panel identified 22 attributes of vanilla ice cream with reduced fat and sugar, and all attributes showed a significant difference $(P<0.05)$ among the samples. Samples with reduced fat and sugar showed a higher intensity of bitter aftertaste, adhesiveness, and firmness, and lower intensity of creaminess. However, the reduction or replacement of fat and sugar did not necessarily cause a decrease in acceptance. The PREF-
MAP, together with the relationship of descriptive attributes and acceptance test, allowed analysis of those attributes that contributed to the acceptance of the ice cream samples. According to our results, the presence and preservation of brightness, creamy appearance, aeration, sweet aroma, powdered milk aroma, white chocolate aroma, sweetness, vanilla flavor, powdered milk flavor, sweet aftertaste, and spreadability, and the lack or suppression of hydrogenated fat aroma and flavor are important for high acceptance of vanilla ice cream.

\section{REFERENCES}

Allgeyer, L. C., M. J. Miller, and S.-Y. Lee. 2010. Sensory and microbiological quality of yogurt drinks with prebiotics and probiotics. J. Dairy Sci. 93:4471-4479.

Astrup, A., S. Tùubro, A. Raben, and A. R. Skov. 1997. The role of low-fat diets and fat substitutes in body weight management: 
What have we learned from clinical studies? J. Am. Diet. Assoc. 97:S82-S87.

BahramParvar, M., S. M. A. Razavi, and M. H. H. Khodaparast. 2010. Rheological characterization and sensory evaluation of a typical soft ice cream made with selected food hydrocolloids. Food Sci. Technol. Int. 16:79-88.

Bayarri, S., I. Carbonell, E. X. Barrios, and E. Costell. 2011. Impact of sensory differences on consumer acceptability of yoghurt and yoghurt-like products. Int. Dairy J. 11:111-118.

Bayarri, S., M. Mart, I. Carboneel, and E. Costel. 2012. Identifying drivers of liking for commercial spreadable cheeses with different fat content. J. Sens. Stud. 27:1-11.

Bolini, H. M. A., M. A. A. P. Silva, and M. H. Damasio. 1999. Measurement of the relative sweetness of stevia, aspartame, and cyclamate/saccharin blend as compared to sucrose at different concentrations. Plant Foods Hum. Nutr. 54:119-130.

Braghieri, A., A. Girolami, A. Carlucci, N. Piazzolla, A. M. Riviezzi, and F. Napolitano. 2009. Sensory properties affecting acceptability of "bresaola" from podolian young bulls. J. Sens. Stud. 24:677697.

Brasil. 1998. Regulamento técnico referente a informação nutricional complementar. Portaria no. 27, 13 de janeiro de 1998. Accessed Jun. 16, 2010. http://www.anvisa.gov.br/legis/portarias/27_98. htm.

Buyck, J. R., R. J. Baer, and J. Choi. 2011. Effect of storage temperature on quality of light and full-fat ice cream. J. Dairy Sci. 94:2213-2219.

Caillet, A., C. Cogne, J. Andrieu, P. Laurent, and A. Rivoire. 2003. Characterization of ice cream structure by direct optical microscopy. Influence of freezing parameters. Lebenson. Wiss. Technol. 36:743-749.

Calviño, A., D. Garrido, and M. García. 2000. Potency of sweetness of aspartame, D-tryptophan and thaumatin evaluated by single value and time-intensity measurements. J. Sens. Stud. 15:47-64.

Cardoso, J. M. P., and H. M. A. Bolini. 2008. Descriptive profile of peach nectar sweetened with sucrose and different sweeteners. J. Sens. Stud. 23:804-816.

Chung, S. J., H. Heymann, and I. U. Grun. 2004. Release of artificial cherry flavor from ice creams varying in fat and fat replacers. J. Sens. Stud. 19:211-236.

Cruz, A. G., A. E. C. Antunes, A. L. O. P. Sousa, J. A. F. Faria, and S. M. I. Saad. 2009. Ice cream as probiotic food carrier. Food Res. Int. 42:1233-1239.

Cruz, A. G., R. S. Cadena, J. A. Faria, C. A. F. Oliveira, R. N. Cavalcanti, E. Bona, H. M. A. Bolini, and M. A. A. P. Da Silva 2011. Consumer acceptability and purchase intent of probiotic yoghurt with added glucose oxidase using sensometrics, artificial neural networks and logistic regression. Int. J. Dairy Technol. 64:549-556.

Cruz, A. G., R. S. Cadena, E. H. M. Walter, A. M. Mortazavian, D. Granato, J. A. F. Faria, and H. M. A. Bolini. 2010. Sensory analysis: Relevance for prebiotic, probiotic, and synbiotic product development. Comp. Rev. Food Sci. Saf. 9:358-373.

Damásio, M. H., and E. Costell. 1991. Análisis sensorial descriptivo: Generación de descriptores y selección de catadores. Rev. Agroq. Tec. Alim. 31:165-178.

Di Criscio, T., A. Fratianni, R. Mignogna, L. Cinquanta, R. Coppola, E. Sorrentino, and G. Panfili. 2010. Production of functional probiotic, prebiotic, and synbiotic ice creams. J. Dairy Sci. 93:45554564.

Dooley, L., Y.-S. Lee, and J.-F. Meullenet. 2010. The application of check-all-that-apply (CATA) consumer profiling to preference mapping of vanilla ice cream and its comparison to classical external preference mapping. Food Qual. Prefer. 21:394-401.

Erkaya, T., E. Dağdemir, and M. Şengül. 2012. Influence of Cape gooseberry (Physalis peruviana L.) addition on the chemical and sensory characteristics and mineral concentrations of ice cream. Food Res. Int. 45:331-335.

Euromonitor International. 2002. Vanilla-Ice cream's enduring flavour. Accessed Jun. 10, 2008. http://www.euromonitor.com/Vanilla_ice_creams_enduring_flavour.
Ferraz, J. L., A. G. Cruz, R. S. Cadena, U. M. Pinto, M. F. Queiroz, C. C. Carvalho, J. A. F. Faria, and H. M. A. Bolini. 2012. Sensory acceptance and survival of probiotic bacteria in ice cream produced with different overrun levels. J. Food Sci. 77:S24-S28.

Frandsen, L. W., G. B. Dijksterhuis, H. Martens, and M. Martens. 2007. Consumer evaluation of milk authenticity explained both by consumer background characteristics and by product sensory descriptors. J. Sens. Stud. 22:623-638.

Frøst, M. B., H. Heymann, W. L. P. Bredie, G. B. Dijksterhuis, and M. Martens. 2005. Sensory measurement of dynamic flavor intensity in ice cream with different fat levels and flavorings. Food Qual. Prefer. 16:305-314.

Guinard, J.-X., B. Uotani, and P. Schlich. 2001. Internal and external mapping of preferences for commercial lager beers: Comparison of hedonic rating by consumers blind versus with knowledge of brand and price. Food Qual. Prefer. 12:243-255.

Guinard, J.-X., C. Zoumas-Morse, L. Mori, D. Panyam, and A. Kilara. 1996. Effect of sugar and fat on the acceptability of vanilla ice cream. J. Dairy Sci. 79:1922-1927.

Guinard, J.-X., C. Zoumas-Morse, L. Mori, B. Uatoni, D. Panyam, and A. Kilara. 1997. Sugar and fat effects on sensory properties of ice cream. J. Food Sci. 5:1087-1094.

Hanger, L. Y., A. Lotz, and S. Lepeniotis. 1996. Descriptive profiles of selected high intensity sweeteners (HIS), HIS blends and sucrose. J. Food Sci. 62:456-459.

Hatchwell, L. C. 1994. Overcoming flavor challenges in low-fat frozen desserts. Food Technol. 48:98-102.

Helgesen, H., R. Solheim, and T. Naes. 1997. Consumer preference mapping of dry fermented lamb sausages. Food Qual. Prefer. 8:97-109

Higurashi, S., Y. Kunieda, H. Matsuyama, and H. Kawakami. 2007. Effect of cheese consumption on the accumulation of abdominal adipose and decrease in serum adiponectin levels in rats fed a calorie dense diet. Int. Dairy J. 17:1224-1231.

Hough, G., and R. Sanchez. 1998. Descriptive analysis and external preference mapping of powdered chocolate milk. Food Qual. Prefer. 9:197-204.

Hyvönen, L., M. Linna, H. Tuorila, and G. Dijksterhuis. 2003. Perception of melting and flavor release of ice cream containing different types and contents of fat. J. Dairy Sci. 86:1130-1138.

Isik, U., D. Boyacioglu, E. Capanoglu, and D. Nilufer Erdil. 2011. Frozen yogurt with added inulin and isomalt. J. Dairy Sci. 94:16471656.

Kaaki, D., O. K. Baghdadi, N. E. Najm, and A. Olabi. 2012. Preference mapping of commercial Labneh (strained yogurt) products in the Lebanese market. J. Dairy Sci. 95:521-532.

Karaca, O.B., M. Güven, K. Yasar, S. Kaya, and T. Kahayoglu. 2009. The functional, rheological and sensory characteristics of ice creams with various fat replacers. Int. J. Dairy Technol. 62:93-99.

King, S. C., P. J. Lawler, and J. K. Adams. 2000. Effect of aspartame and fat on sweetness perception in yogurt. J. Food Sci. 65:1056-1059

Kuo, L. E., M. Czarnecka, J. B. Kitlinska, J. U. Tilan, R. Kvetnansky, and Z. Zukowska. 2008. Chronic stress, combined with a high-fat/ high-sugar diet, shifts sympathetic signaling toward neuropeptide $\mathrm{Y}$ and leads to obesity and the metabolic syndrome. Ann. NY Acad. Sci. 1148:232-237.

La Serre, C. B., C. L. Ellis, J. Lee, A. L. Hartman, J. C. Rutledge, and H. E. Raybould. 2010. Propensity to high-fat diet-induced obesity in rats is associated with changes in the gut microbiota and gut inflammation. Am. J. Physiol. 299:G440-G448.

Lawlor, J. B., and C. M. Delahunty. 2000. The sensory profile and consumer preference for ten speciality cheeses. Int. J. Dairy Technol. 53:28-36

Li, Z., R. Marshall, H. Heymann, and L. Fernando. 1997. Effect of milk fat content on flavor perception of vanilla ice cream. J. Dairy Sci. 80:3133-3141.

MacFie, H. J. H., N. Bratchell, K. Greenhoff, and L. V. Vallis. 1989. Designs to balance the effect of order of presentation and firstorder carry-over effects in hall tests. J. Sens. Stud. 4:129-148. 
Marshall, R. T., and W. S. Arbuckle. 1996. Ice Cream. 5th ed. Thomson International Publishing, New York, NY.

Meilgaard, M., G. V. Civille, and B. T. Carr. 2007. Descriptive analysis techniques. Pages 167-168 in Sensory Evaluation Techniques. 4th ed. CRC Press, Boca Raton, FL.

Melo, L. L. M. M., H. M. A. Bolini, and P. Efraim. 2009. Sensory profile, acceptability, and their relationship for diabetic/reduced calorie chocolates. Food Qual. Prefer. 20:138-143.

Moskowitz, H. R. 1983. Product Testing and Sensory Evaluation of Foods. Food and Nutrition Press, Westport, CT.

Muse, M. R., and R. W. Hartel. 2004. Ice cream structural elements that affect melting rate and hardness. J. Dairy Sci. 87:1-10.

Ochi, H., M. Sumi, I. Nakata, H. Saito, M. Uozumi, and K. Iwatsuk. 2010. Sensometric calibration of sensory characteristics of commercially available milk products with instrumental data. J. Dairy Sci. 93:1794-1806.

Ohmes, R. L., R. T. Marshall, and H. Heyman. 1998. Sensory and physical properties of ice creams containing milk fat or fat replacers. J. Dairy Sci. 81:1222-1228.

Ozdemir, C., E. Dagdemir, S. Salih Ozdemir, and O. Sagdic. 2008 The effects of using alternative sweeteners to sucrose on ice cream quality. J. Food Qual. 31:415-428.

Pereira, R. B., R. J. Bennett, and M. S. Luckman. 2005. Instrumental and sensory evaluation of textural attributes in cheese analogs: A correlation study. J. Sens. Stud. 20:434-453.

Portmann, M. O., and D. Kilcast. 1996. Psychophysical characterization of new sweeteners of commercial importance for the EC food industry. Food Chem. 56:291-302.

Ritvanen, T., L. Lllebergm, T. Tupasela, U. Suhonen, S. Eerola T. Putkonen, and K. Peltonen. 2010. The characterization of the most-liked reduced-fat Havarti-type cheeses. J. Dairy Sci. 93:5039-5047.

Roland, A. M., L. G. Phillips, and K. J. Boor. 1999. Effects of fat replacers on the sensory properties, color, melting, and hardness of ice cream. J. Dairy Sci. 82:2094-2100.

Ruxton, C. H. S., E. J. Gardner, and H. M. McNulty. 2010. Is sugar consumption detrimental to health? A review of the evidence: 1995-2006. Crit. Rev. Food Sci. Nutr. 10:1-19.

Saris, W. H. M. 2003. Sugars, energy metabolism and body weight control. Am. J. Clin. Nutr. 78:850S-857S

Schrauwen, P., and K. R. Westerterp. 2000. The role of high-fat diets and physical activity in the regulation of body weight. Br. J. Nutr. $84: 417-427$.
Sofjan, R. P., and R. W. Hartel. 2004. Effects of overrun on structural and physical characteristics of ice cream. Int. Dairy J. 14:255-262.

Soukoulis, C., D. Lebesi, and C. Tzia. 2009. Enrichment of ice cream with dietary fibre: Effects on rheological properties, ice crystallisation and glass transition phenomena. Food Chem. 115:665-671.

Soukoulis, C., E. Rontogianni, and C. Tzia. 2010a. Contribution of thermal, rheological and physical measurements to the determination of sensorially perceived quality of ice cream containing bulk sweeteners. J. Food Eng. 100:634-641.

Soukoulis, C., E. Lyroni, and C. Tzia. 2010b. Sensory profiling and hedonic judgement of probiotic ice cream as a function of hydrocolloids, yogurt and milk fat content. Lebenson. Wiss. Technol. 43:1351-1358

Stampanoni-Koeferli, C. R., P. Piccinali, and S. Sigrist. 1996. The influence of fat, sugar and non-fat milk solids on selected taste, flavor and texture parameters of a vanilla ice-cream. Food Qual. Prefer. 7:69-79.

Stone, H., and J. Sidel. 2004. Quantitative descriptive analysis (the QDA method). Pages 215-235 in Sensory Evaluation Practices. 3rd ed. Elsevier Academic Press, San Diego, CA.

Sun-Waterhouse, D., L. Edmonds, S. S. Wadhwa, and R. Wibisono. 2011. Producing ice cream using a substantial amount of juice from kiwifruit with green, gold and red flesh. Food Res. Int. http://dx.doi.org/10.1016/j.foodres.2011.05.030

Tenenhaus, M., J. Pagès, L. Ambroisine, and C. Guinot. 2005. PLS methodology to study relationships between hedonic judgments and products characteristics. Food Qual. Prefer. 16:315-325.

Tharp, B. W., B. Forrest, C. Swan, L. Dunning, and M. Hilmoe. 1998. Basic factors affecting ice cream meltdown. Pages 54-64 in Ice Cream: Proc. Int. Symp., Athens, Greece. W. Buchheim, ed. International Dairy Federation, Brussels, Belgium.

Thompson, K. R., D. H. Chambers, and E. Chambers. 2009. Sensory characteristics of ice cream produced in the U.S.A. and Italy. J. Sens. Stud. 24:396-414.

Wadhwani, R., and D. J. McMahon. 2012. Color of low fat cheese influences flavor perception and consumer liking. J. Dairy Sci. 95:2336-2346.

Weiss, R., J. Dziura, T. S. Burgert, W. V. Tamborlane, S. E. Taksali, C. W. Yeckel, K. Allen, M. Lopes, M. Savoye, J. Morrison, R. S. Sherwin, and S. Caprio. 2004. Obesity and the metabolic syndrome in children and adolescents. N. Engl. J. Med. 350:2362-2374. 